\title{
부산 글로벌 파트너십 출범과 우리나라 ODA 정책과제
}

홍 상 희 (외교통상부 개발정책과 2등서기관)

\section{목 차}

1. 서론

2. 부산 글로벌 파트너십 개요

가. 그간 논의 경과

나. 글로벌 파트너십의 기능과 운영체제

다. 의의 및 평가

3. 국내 이행 방안과 주요 정책과제

가. 글로벌 파트너십 집행위원회 참여

나. 주요 원조효과성/개발효과성 공약 이행

다. 부산총회 Building Blocks 및 자발적 이니셔티브 참여

라. 개도국 현장 중심 개발협력 강화

마. 국내 Multi-stakeholder 개발협력 파트너십 구축

4. 결어

\section{1. 서론}

지난 6월말 파리 유엔교육·과학·문화기구(UNESCO) 본부에서 열린 경제협력개발기구 (OECD) 산하 원조효과작업반(Working Party on Aid Effectiveness) 최종 회의에서 "효과 적인 개발협력을 위한 부산 파트너십(일명: 글로벌 파트너십)1)” 이 공식 출범하였다. 
이로써 7개월 전 부산 세계개발원조총회(2011.11.29-12.1)에서 3,000여명의 참석자들이 21 세기 개발협력의 새로운 비전으로 제시한 주요 공약을 이행할 수 있는 실질적인 운영체제가 만 들어졌다.

부산총회는 UN 새천년개발목표(MDGs) 달성 시한을 불과 4년 앞두고 개발협력 분야에서 개 최된 최대 규모 - 최고 권위의 행사로써, 개발도상국의 빈곤퇴치와 지속가능한 발전을 위한 국 제사회의 노력을 새로이 결집하는 전기를 마련한 것으로 평가받고 있다. 부산총회 결과물로 채 택된 글로벌 파트너십이 성공적으로 그 기능을 수행할지 여부는 글로벌 파트너십을 구성하는 모든 개발주체들의 적극적인 참여와 이행 의지에 달려 있다고 하겠다.

이 글에서는 부산총회에서 합의되어 새롭게 출범된 글로벌 파트너십의 의의를 살펴보고, 부산 총회 공약 및 합의사항 이행과 함께 글로벌 파트너십을 국내적으로 내재화하기 위한 우리나라 주요 정책과제와 추진방향을 모색해 보고자 한다.

\section{2. 부산 글로벌 파트너십 개요}

\section{가. 그간 논의 경과}

부산총회는 향후 글로벌 개발 커뮤니티가 나아갈 방향으로 정부, 국제기구, 시민사회, 의회, 민간 등 모든 개발주체가 참여하는 포괄적인 글로벌 파트너십 구축에 합의하고, 동 파트너십의 구체적인 운영방안을 2012년 6월까지 마련키로 결정했다.

동 합의사항 이행을 위해 $\mathrm{OECD}$ 개발원조위원회(DAC) 산하 원조효과작업반의 기능이 6개월 간 연장되었고, 부산총회 결과문서 협상을 담당했던 쉐르파 체제를 확대하여 '포스트 부산 임시 그룹(PBIG: Post-Busan Interim Group)'이 구성2)되었다.

1) 우리는 새롭고 포괄적인 '효과적인 개발협력을 위한 글로벌 파트너십' (Global Partnership for Effective Development Co-operation)을 구축하여, 정치적 수준에서 약속 이행을 지원하고 책무성을 갖도록 한다. 동 파 트너십은 다양성을 포용하는 열린 플랫폼을 통해 지식의 교환과 주기적으로 진전사항을 검토하는 포럼을 구축한 다. (부산총회 결과문서 제36조 $a$ 항)

2) 우리나라는 원조효과작업반 부의장국이자 PBIG 멤버로 post-Busan 후속 논의에 참여 
PBIG 멤버는 전통 공여국, 신흥국, 개도국, 시민사회, 민간 대표 등 총 25 명으로 구성되었으 며, 부산총회 이후 총 3 차례에 걸쳐 회의를 개최, 글로벌 파트너십의 운영체제와 글로벌 모니터 링 방안에 관한 광범위한 의견을 수렴하였다. 이러한 협의 결과를 반영한 최종 제안서가 지난 6 월 28일부터 29일까지 이틀간 파리 UNESCO 본부에서 열린 원조효과작업반 최종 회의에서 승인되었다.

$\mathrm{PBIG}$ 의 제안서는 모든 원조효과작업반 멤버 및 여타 개발주체들의 기대 수준을 충족시키지 는 못했다. 특히, 시민사회, 아프리카 개도국, 지역기구 등은 글로벌 파트너십 거버넌스 체제에 대한 참여 확대를 요구했지만, 글로벌 파트너십의 효과적 운영을 위해서는 참여 범위의 제한이 불가피하고 참여 범위에 대한 협상을 다시 시작할 경우 부산총회에서 합의된 기한 내 글로벌 파 트너십 출범은 불가하다는 점 등을 감안, PBIG 제안을 그대로 수용했다. 이로써 국제사회의 원 조효과성 논의를 이끌어 왔던 $\mathrm{OECD}$ 원조효과작업반과 산하 조직의 모든 활동이 종료되고, 이 를 대체하는 새로운 개발협력 거버넌스 체제인 글로벌 파트너십이 공식 출범했다.

\section{나. 글로벌 파트너십의 기능과 운영체제}

글로벌 파트너십의 기능은 크게 네 가지다. 우선, 기존 원조효과성 논의가 기술적인 면에 치 우친 한계를 고려, 부산총회에서 합의된 효과적인 개발협력을 위한 정치적 모멘텀을 강화해 나 가는 것이다. 또한, 부산총회 합의사항 이행을 위한 책임성을 확보하고, 다양한 개발주체 간 지 식 공유와 경험 공유를 활성화하며, 개도국 현장에서의 부산총회 합의사항 이행을 지원하는 역 할을 담당한다.

글로벌 파트너십 운영체제는, i) 최고 의사결정을 담당하는 장관급 회의, ii) 글로벌 파트너십 의 실제 운영을 담당하는 집행위원회, iii) 사무국 기능을 수행하는 OECD-UNDP 공동 지원팀 으로 구성되며, 부산총회 주요 합의사항을 점검하기 위한 글로벌 모니터링 체제가 도입된다.

(1) 장관급 회의(Ministerial Meeting)

장관급 회의는 부산총회 합의사항 이행 점검을 주목적으로 하되, post-MDGs 등 새롭게 부 상하는 개발 이슈를 논의하는 고위급 정책대화의 장으로써, $18-24$ 개월을 주기로 $\mathrm{UN}, \mathrm{OECD}$, 다자개발은행 등 여타 고위급 개발회의와 연계 개최 등을 포함하여 신축적으로 운영하기로 하 였다. 동 장관급 회의에는 부산총회 결과문서를 승인한 국가와 기관은 모두 참여할 수 있다. 
(2) 집행위원회(Steering Committee)

장관급 회의의 의제 준비 등 글로벌 파트너십의 실질운영은 18 명으로 구성된 집행위원회가 담당한다. 집행위원회는 공여국, 신흥국, 수원국의 장관급 공동의장 3 명과 공여국, 신흥국, 수 원국, 의회, 시민사회, 민간, 다자개발은행, UNDP, $\mathrm{OECD}$ 출신 15 명의 집행위원으로 구성된 다.

우리나라는 부산 파트너십 구축과정에서의 기여를 인정받아 영국(공동의장), $\mathrm{EU}$, 미국과 더 불어 공여국 대표로 집행위원회에 참여할 예정이다.

(3) OECD-UNDP 공동 지원팀(Joint Support Team)

부산총회가 지향하는 "global light, country focused" 이행체제를 효과적으로 지원하기 위 한 OECD-UNDP 공동 지원팀(Joint Support Team)은 기존 OECD와 UNDP의 조직과 인력 을 활용하여 운영될 계획이다. $\mathrm{OECD}$ 는 글로벌 모니터링과 공여국에 대한 이행 점검을, UNDP 는 현장 중심의 부산총회 합의사항 이행을 지원함으로써 각 기관의 비교우위를 바탕으로 한 협 력체제가 구축될 예정이다.

(4) 글로벌 모니터링 지표(Busan Global Monitoring Indicators)

부산총회에서 합의된 주요 원조효과성 및 개발효과성 공약의 이행을 점검하기 위하여 10 개의 글로벌 모니터링 지표가 선정되었다. 수원국 시스템 활용(지표 9), 비구속화(지표 10), 원조 예 측성(지표 5), 투명성(지표 4) 등 파리지표를 유지 또는 심화, 발전시킨 것도 일부 있지만, 시민 사회(지표 2), 민간분야(지표 3), 양성평등(지표 8) 등은 새롭게 추가된 지표들이다. 10 개 지표 중 시민사회와 민간분야 관련 지표는 추가적인 협의가 필요한 상황이며, 최종 지표의 정의와 측 정 방법 등은 기술적 검토를 거쳐 금년 말까지 확정키로 하였다.

또한, 부산 글로벌 모니터링 체제는 부산총회에서 합의된 공약 중 글로벌 차원에서 모니터링 할 필요성이 있는 분야를 중심으로 선정되었으며, 모니터링 지표에서 제외된 공약들은 개도국 국별 모니터링 및 장관급 회의에서 이행 여부를 점검할 수 있다. 부산 글로벌 모니터링은 자발 적인 참여를 원칙으로 하며, 특히 남남협력국에 대해서는 글로벌 파트너십 참여와 글로벌 모니 터링 참여를 분리함으로써 글로벌 모니터링에 참여하지 않더라도 글로벌 파트너십의 정책대화 에 참여할 수 있는 정책적 융통성을 부여했다. 
〈표 1〉 부산 글로벌 모니터링 지표(안)

\begin{tabular}{|c|c|c|c|}
\hline 부산 글로벌 지표 & 지표 설명 & 목표치(2015년) & $\begin{array}{l}\text { 부산 } \\
\text { 결과문서 } \\
\text { 관련 조항 }\end{array}$ \\
\hline 1. 수원국 우선순위 반영 & $\begin{array}{l}\text { 수원국의 우선순위를 반영 } \\
\text { 한 결과 프레임워크 활용 } \\
\text { 정도 }\end{array}$ & $\begin{array}{l}\text { 모든 공여주체가 수원국 } \\
\text { 결과 프레임워크 활용 }\end{array}$ & $18(a)$ \\
\hline 2.시민사회의 참여와 기여 & $\begin{array}{l}\text { CIVICUS 시민사회 환경 지 } \\
\text { 수(Enabling environment } \\
\text { index) 활용 }\end{array}$ & 지속적 향상 & 22(a) \\
\hline 3. 민간분야의 역량강화 & 추후 확정 & 지속적 향상 & $32(a)$ \\
\hline 4. 개발협력 정보 공개 & 공통의 공개 표준 활용 정도 & 모든 공여주체가 활용 & 23(c) \\
\hline 5. 예측 가능성 & 개발협력의 예측 가능성 제고 & & \\
\hline (a) 단기 예측성 & 해당 년도 계획된 원조의 집행 비율 & 집행되지 않은 비율 $50 \%$ 감소 & 24(a) \\
\hline (b) 중기 예측성 & 중기 집행계획에 포한된 원조 비율 & 포함되지 않은 비율 $50 \%$ 감소 & \\
\hline 6. 원조의 예산화 & $\begin{array}{l}\text { 개도국 의회 승인을 받은 } \\
\text { 연간 예산에서 원조 비율 } \\
\text { (2010년 기준) }\end{array}$ & $\begin{array}{l}\text { 정부에 지원되는 개발원조 } \\
\text { 중 정부 예산에 보고되지 } \\
\text { 않은 비율 } 50 \% \text { 감소 }\end{array}$ & 21(a) \\
\hline 7. 상호 책임성 & $\begin{array}{l}\text { 부산총회 합의사항 이행을 } \\
\text { 위한 포괄적인 상호평가 검 } \\
\text { 토 참여 }\end{array}$ & 모든 개도국에서 도입 & 35(a) \\
\hline $\begin{array}{l}\text { 8. 양성평등과 여성 역량 } \\
\text { 강화 }\end{array}$ & $\begin{array}{l}\text { 양성평등과 여성의 역량강 } \\
\text { 화를 위한 공공예산 배정과 } \\
\text { 이를 트래킹하는 시스템을 } \\
\text { 가진 국가의 비율(\%) }\end{array}$ & 모든 개도국에서 도입 & 20(a) \\
\hline 9. 수원국 시스템 활용 & \multirow{3}{*}{$\begin{array}{l}\text { 효과적인 제도 구축을 위한 } \\
\text { 개도국 시스템 강화 및 활 } \\
\text { 용(2010년 기준) }\end{array}$} & & \multirow{3}{*}{$19(a)$} \\
\hline $\begin{array}{l}\text { (a)개도국 공공재정관리 } \\
\text { 시스템(PMF)의 질적 } \\
\text { 수준 }\end{array}$ & & $\begin{array}{l}\text { 개도국 } 50 \% \text { 이상에서 } \\
\text { PFM/CPIA 점수 최소 1단 } \\
\text { 계 상승 }\end{array}$ & \\
\hline $\begin{array}{l}\text { (b)수원국 PMF 및 조달 } \\
\text { 시스템 활용 }\end{array}$ & & $\begin{array}{l}\text { 시스템을 사용하지 않는 비 } \\
\text { 율 감축 }\end{array}$ & \\
\hline 10. 비구속화 & $\begin{array}{l}\text { 비구속성 원조 비율(\%) } \\
\text { (2010년 기준) }\end{array}$ & 지속적 향상 & $18(e)$ \\
\hline
\end{tabular}




\section{다. 의의 및 평가}

부산총회는 로마, 파리, 아크라로 이어진 원조효과성 논의를 마무리하는 회의에 그치지 않고 실제로 개도국의 발전을 가져올 수 있는 요인과 임팩트에 중점을 둔 개발효과성(development effectiveness)이라는 새로운 화두를 제시했다. 비록 개발효과성이라는 개념이 명시적으로 결 과문서에 포함되지는 않았으나, 기존 공적개발원조(ODA: Official Development Assistance) 중심의 논의를 넘어 남남협력, 민간 개발활동 등 비원조(non-aid) 분야와 다양한 개발주체의 역할과 기여를 인정하면서 과거 공여국-수원국의 수직적 관계가 아닌 다양한 개발 주체가 수평적으로 참여하는 새로운 글로벌 개발 거버넌스 체제다. 부산총회에서 합의되어 새 롭게 출범된 글로벌 파트너십은 여타 글로벌 개발 프로세스와는 차별화된 특징과 의의를 갖고 있다.

첫째, 개발협력 역사상 최초로 다양한 개발주체가 참여하는 ”다주체(multi-stakeholder)“ 운영체제를 구축했다는 점이다. UN, G20, 다자개발기구 중심의 개발협력 논의는 모두 회원국 정부를 중심으로 운영되지만 글로벌 파트너십은 정부뿐만 아니라 국제기구, 비정부 기관(의회, 민간, 시민사회) 등 모든 개발 주체가 옵서버가 아닌 동등한 파트너로 글로벌 파트너십의 실질 운영에 참여하게 된다.

둘째, 기존 선진국(OECD) 주도의 효과성(effectiveness) 논의를 종료한다는 점이다. 부산총 회는 개도국 스스로가 개발의 주인이 되어야 한다는 점을 재확인하였고, 수원국 현장 중심의 포 스트 부산 이행체제를 도입했다. 또한, 글로벌 파트너십의 실질적인 운영을 담당하는 집행위원 회의 가장 많은 자리(18명중 6명)를 수원국에게 배분함으로써 수원국의 목소리와 입장이 충분 히 반영될 수 있는 제도적 기반을 마련했다.

셋째, 글로벌 파트너십은 느슨한(loose) 형태로 운영되지만 지속적으로 진화한다는 점이다. 이는 신흥국 등 다양한 개발주체의 참여를 이끌어내기 위한 정치적 타협과 협상의 산물이기도 하다. 다양한 개발주체의 참여가 부산총회의 공약 이행 의지를 약화시키거나 국제사회의 규범 을 희석시키는 방향으로 해석되는 것은 바람직하지 않다. 글로벌 파트너십은 오늘날 중요한 개 발 파트너로 급부상한 신흥국, 민간 주체들이 효과적인 개발협력이라는 공통의 목표를 달성하 기 위한 고위급 정책 대화에 참여할 수 있는 제도화된(formalized) 공간을 마련했다는 점에서 의의가 크다. 


\section{3. 국내 이행 방안과 주요 정책과제}

부산총회 이후 $\mathrm{EU}$, 영국, 가나, 베트남, 잠비아 등 다수 국가들은 부산총회 합의사항을 이행 하기 위한 자체 이행계획을 수립했거나 수립 중에 있다. 우리나라는 2010년 OECD DAC에 가 입한 신규 회원국으로서 여타 선진국과 동일한 수준의 선진 원조 규범과 기법을 활용하는데 한 계가 있는 것이 사실이다. 하지만, 부산총회 개최국으로서 새로운 글로벌 파트너십의 성공적인 운영을 지원하고, 부산총회 합의사항과 공약을 이행해 나가는 것은 도의적인 책임뿐만 아니라 우리 $\mathrm{ODA}$ 정책 및 집행을 선진화하는데도 기여할 것이다.

\section{가. 글로벌 파트너십 집행위원회 참여}

우리나라는 향후 2 년간 글로벌 파트너십의 실질사항을 담당하는 집행위원회 위원으로 참여하 여 부산총회 개최국으로서의 리더십과 기여를 지속해 나갈 계획이다. 무엇보다 새로운 글로벌 파트너십의 운영의 성패는 정치적인 모멘텀 유지와 모든 개발주체의 적극적인 참여에 달려 있 다. 이러한 측면에서 최근 글로벌 파트너십을 이끌어 갈 공여국, 수원국, 신흥국 공동의장으로 영국, 나이지리아, 인도네시아 장관급 인사가 각각 선임된 것은 환영할 만한 일이다.

현재 주요 신흥국 중 글로벌 파트너십에 참여하겠다고 공식 입장을 표명한 국가는 인도네시 아, 멕시코, 남아공 정도다. 중국과 인도는 부산총회와 후속 논의에 참여해 왔지만 아직까지 글 로벌 파트너십의 정식 멤버로 참여하는데 신중한 입장을 보이고 있다. 하지만, 글로벌 파트너십 이 진화하고, 공여국으로서의 그들의 역량이 강화되면 부산총회 공약 이행에 점진적으로 동참 하겠다는 의사를 표명했다.

우리나라는 부산총회 결과문서 협상 및 후속논의 과정에서 중국, 인도, 브라질 등 신흥국의 참여를 이끌어 내고, 전통 공여국과 신흥국 간 가교 역할을 훌륭히 수행한 경험을 갖고 있다. 이 러한 경험을 살려, 글로벌 파트너십이 '부산 정신' 을 계승하여 건설적인 방향으로 발전해 나갈 수 있도록 외교력을 발휘할 필요가 있다.

\section{나. 주요 원조효과성/개발효과성 공약 이행}

부산총회에서는 파리/아크라 원조효과성의 핵심 공약을 재확인한 바 있다. 특히, 수원국 시스템 활용, 원조 예측성 강화, 투명성 제고, 원조의 비구속화 관련 공약은 글로벌 모니터링 지표로도 포함되면서 공여국들의 이행 의무가 더욱 강화되었다고 볼 수 있다. 
부산총회의 원조효과성 공약을 이행하기 위해서는 개별 공약 이행에 앞서 우리 ODA 정책과 집행체제의 전반적인 변화가 필요하다. 특히, 기존 프로젝트 중심의 원조 관행 하에서는 부산총 회에서 합의된 공약들을 충실히 이행해 나가는데 한계가 있을 수밖에 없다. 이를 해결하기 위해 서는 프로그램 기반 접근(program-based approach)의 점진적 도입 등 우리 ODA 집행체제 에 대한 보다 체계적이고, 종합적인 정책 검토가 병행되어야 할 것이다. 또한, 부산총회 합의사 항을 기존 중 - 단기 $\mathrm{ODA}$ 전략 및 예산계획에 반영하는 작업이 필요하다. 통합국별협력전략 (CPS)과 글로벌 파트너십 연계를 통한 수원국 개별 상황에 맞는 이행방안도 필요하다.

한편, 상대적으로 구체화되어 있는 원조효과성 공약과 달리 효과적인 개발협력(또는 개발효과 성) 관련 공약들은 구체적인 목표치가 합의되어 있지는 않지만 국제사회가 지향하는 정책방향 을 제시하고 있다. 우리나라가 주도적으로 의제화한 남남/삼각협력, 민간의 역할, 효과적인 제 도 관련 합의사항 이행을 위한 구체화된 후속조치가 마련되어야 할 것이다. 부산총회 합의사항 을 효과적으로 이행하기 위해서는 주요 공여국, 국제기구와의 전략적인 파트너십을 구축하는 것도 유용한 전략이 될 수 있을 것이다.

\section{다. 부산총회 빌딩블록(Building Blocks) 및 자발적 이니셔티브 참여}

부산총회에서는 공식적인 결과문서 외에도 부산총회 결과문서 이행을 위해 관심 있는 국가, 기관들이 리더십을 갖고 자발적으로 추진하는 8개의 빌딩블록(Building Blocks)3)과 양성평등 관련 글로벌 이니셔티브들이 있다. 빌딩블록과 자발적 이니셔티브는 글로벌 파트너십과 공식적 으로 연계되어 있지는 않지만, 부산 합의사항의 실질적인 진전과 성과를 가져 올 수 있는 영역 이다.

우리나라가 참여하고 있는 효과적인 제도, 양성평등, 민간분야 관련 빌딩블록 및 자발적 이니 셔티브에 효율적으로 참여하기 위해서는 국내 전문성을 가진 관계부처, 기관과의 협력 관계 구 축이 중요하다.

\section{라. 개도국 현장 중심의 개발협력 강화}

부산총회 이후 지금까지의 논의는 글로벌 레벨의 파트너십 구축에 초점이 맞추어져 왔다. 그

3) 분쟁 및 취약국가, 남남 및 삼각협력, 민간부문, 기후변화 재원, 투명성, 효과적 제도와 정책, 결과와 상호 책무성, 원조 분절화 감소 
러나 앞으로는 부산총회에서 지향하는 개도국 현장 중심의 이행을 위해 개별 개도국 현장에서 의 글로벌 파트너십 또는 "country compact" 구축 논의가 본격화될 전망이다. 현재 베트남, 가나 등지에서 수원국 주도의 글로벌 파트너십 구축 노력이 진행 중이다. 우리나라는 이러한 노 력을 적극 지원하고 동참할 필요가 있으며, 이를 위해 해당 개도국에서 이루어지고 있는 우리 개발협력 활동을 종합적으로 파악하고 있는 재외공관 중심의 지원 체제를 제도화할 필요가 있 다.

\section{마. 국내 multi-stakeholder 개발협력 파트너십 구축}

부산총회 합의사항을 효율적으로 이행하기 위해서는 국내 차원의 다주체(multistakeholder) 파트너십 구축이 필요하며, 특히, 시민사회나 민간기업 등 민간분야 개발주체의 자발적인 참여와 적극적 기여를 유도할 수 있는 제도적 틀과 인센티브 마련이 필요하다. 초기 이행 단계에서는 정보공유 및 정책대화를 통한 상호 인식 제고와 파트너십의 기반을 형성하고, 점차적으로 협력 범위를 확대해 나가는 전략이 필요할 것으로 보인다.

\section{4. 결어}

부산총회에서 합의된 글로벌 파트너십은 국제개발협력의 새로운 출발점이자 패러다임 전환을 의미한다. 이처럼 많은 변화를 가져올 글로벌 파트너십은 국제사회와 부산총회 개최국인 우리 나라에게 새로운 기회와 도전과제를 안겨주었다.

국제사회는 모든 개발주체가 동등한 파트너로 참여하는 포괄적인 파트너십을 출범시킴으로써 국제개발협력 역사의 새로운 장을 열었다. 그만큼 글로벌 파트너십에 대한 기대 또한 높다. 하 지만 다양한 개발주체가 참여한다는 것 자체가 도전과제로도 인식되고 있다. 특히, 주요 신흥국 의 글로벌 파트너십 참여가 담보되지 않은 상황에서 신흥국을 끌어들이기 위해 어렵게 구축해 온 국제개발협력 규범이 와해될 수 있다는 우려도 제기되고 있다. 하지만, 글로벌 파트너십은 이제 막 시작한 단계이므로 부정적인 선입견을 갖고 바라보는 것은 바람직하지 않고, 부산총회 에서 확인된 정치적 의지와 건설적인 타협 정신이 계속 발휘된다면 새로운 개발협력 패러다임 으로 자리매김할 것으로 믿는다.

부산총회 개최국으로서 우리나라가 풀어 나가야 할 과제도 많다. 새로운 글로벌 파트너십 구 
축 과정에 주도적으로 참여하면서 개발협력 분야에서 우리나라의 국제적 위상은 높아졌지만, 우리 ODA 정책이나 제도, 집행체제는 개선해야 할 부분이 많이 남아 있다. 앞으로 진행될 부산 총회 공약과 합의사항 이행을 우리 $\mathrm{ODA}$ 를 한 단계 업그레이드하고 선진화하는 기회로 삼아야 할 것이다. 우리나라의 산파 역할을 통해 출범된 글로벌 파트너십이 유명무실한 정치 공약이 아 닌 개도국들에게 실질적인 발전을 가져오는 매개체 역할을 할 수 있도록 정부와 민간, 시민사 회, 학계 모두가 지혜와 힘을 모아가야 할 때다. 


\section{참고문헌}

\section{1. 국내문헌}

박은하 (2011), “부산 세계개발원조총회 주요 성과 및 향후 과제” 국제개발협력 No. 4, 한국국제협력단.

임소진 (2012), “원조효과성에서 개발효과성으로," 국제개발협력 No.2, 한국국제협력단.

\section{2. 국외문헌}

Homi Kharas (2011), “Coming Together: How a New Global Partnership on Development Cooperation was Forged at the Busan High Level Forum on Aid Effectiveness, Real Insisuto Elcano.

Mark Tran (2012), “Andrew Mitchell given role in post-Busan aid effectiveness panel," The Guardian.

Mark Tran (2012), "New aid effectiveness indicators agreed at post-Busan meeting," The Guardian.

Post Busan Interim Group (2012), Proposed Indicators, Targets and Process for Global Monitoring of the Busan Partnership for Effective Development Cooperation, DCD/DAC/EFF(2012)8/REV1.

Post Busan Interim Group (2012), Proposed Mandate for the Global Partnership for Effective Development Cooperation, DCD/DAC/EFF(2012)7/REV1. 